\title{
Correlation of subcutaneous fat variables with motor ability in females
}

\author{
- Artan R. Kryeziu ${ }^{1,2}$, ๑ Astrit Iseni ${ }^{3}$, ๑ Enver Tahiraj $^{4}$ \\ ${ }^{1}$ Fama College, Faculty of Children Care and Welfare, Prishtina, Kosovo. ${ }^{2}$ Center of Research, Studies in Physical Education, Sport and \\ Health, Prishtina, Kosovo. ${ }^{3}$ University of Tetovo Faculty of Physical Education, Tetovo, Macedonia. ${ }^{4}$ University UBT, Faculty of Sports \\ and Movement Sciences, Prishtina, Kosovo.
}

\begin{abstract}
The aim of the paper was to analyze the correlation of subcutaneous fat tissue variables with motor ability for women aged $11++/-6$ months. In a sample $(n=60)$ of the sixth grade $(V I)$ of the Prishtina municipality, all attend the Physical Education (PE) curriculum. In this paper-experiment 12 variables were applied, 6 of which are morphological characteristics and 6 motor tests. All subjects are of female gender, of the lower secondary schools "Elen Gjika" and "Pjetër Bogdani" from the municipality of Prishtina. Correlative ratios between morphological characteristics and motor ability are relatively low. Also in these two dimensions treated, it is worth mentioning the negative correlative ratio between subcutaneous far variables with motor tests. Based on the results obtained in this experiment as well as the morphological changes of motor skills of this age, the changes in the locomotor system have not yet been developed, and any assignment given to these children presents the difficulty of carrying out a motor duty.
\end{abstract}

Keywords. EUROFIT, females, subcutaneous fat, motor ability.

\section{Introduction}

The determination of relation between morphological characteristics and motor knowledge remains an insufficiently scientifically explored area, although it represents an actual theoretical and practical problem, with high significance for kinesiological education. This is primarily applied to the possibility of forming rational procedures for planning, programming, monitoring and evaluating physical education classes, as well as the orientation and selection of young athletes, further on, planning, programming and controlling the training process, as well as efficiently observing the development of relevant anthropological characteristics of athletes and pupils (Vlahović, 2012; Vlahović et al., 2016). However, in order to adequately apply motor knowledge in kinesiological education, it is important to respect pupils' age, since it has to be based on the biological degree of development of certain abilities in the phases of development. It is possible to learn adequate motor knowledge, which is also a condition for assuming the function of appropriate kinesiological stimulus in the development of pupils' anthropological characteristics (Vlahović, 2012; Kryeziu et al., 2014; Vlahović et al., 2016).

Therefore, the primary value of the knowledge mentioned is the possibility of changing certain anthropological characteristics of students according to a given purpose (Babin et al., 2010; Bavčević et al., 2008). The quality of the process of physical education (PE) depends on a number of factors. One of the decisive factors is to get acquainted with the current state of the student's abilities, characteristics and knowledge, as well as the transformative values of some kinesiological operators i.e. teaching materials in physical education (Findak, 1997; 2003). Irregular physical exercise results in poorer motor development among girls compared to boys. Another reason lies in the fact that girls at this age have already entered puberty, the period when gender dimorphism becomes distinct, and then under the hormonal influences differences in size and body composition become evident, especially affecting higher proportion of body fat in girls (MišigojDuraković, 2008). High level of motor skills is 
extremely important for everyday functioning of human beings. Reducing the level leads to various health problems. Daily physical exercise has a high impact on the development of motor skills that have significant implications on human health. Only sufficiently developed motor skills can largely be one of the prerequisites for good health (Badrić, 2011).

The ability to solve complex tasks with motor skills can be of great importance in everyday life, so the results of this research show that 11-12 year olds can achieve the best results in terms of developing full features motor and the best results in the ability to master the complex driving structure. If we refer to the results obtained from this research and that relate to the motor space, it is good to uniformly observe the results that the same authors have obtained from the research of the impact of morphological characteristics on the success of performing complex driving activities (Madić et al., 2010; Madić et al., 2011). The problems of studying morphological caracteristics and motor skills of children have been the subject of study by pedagogues of physical education (PE) as well as many other experts of this field. This problematic is always present and at the same time it is also in the function of the development and follow-up of the perennial factors that play a very important role in the bio-psycho-social aspect of children. The purpose of this paper was to analyze the correlation of subcutaneous fat variables with motor ability for women aged $11+/-6$ months, who are involved in the teaching process of PE.

\section{Methods}

\section{Participants}

Sample entities, in this paper-experiment are included $(n=60)$ children of lower secondary education, "Elen Gjika" and "Pjetër Bogdani" from the Municipality of Prishtina, all attending the PE curriculum. Children age $11+/-6$ months who attend the sixth grade (VI). All children are able to attend classes in the physical education class. Also, children have realized the same tasks as foreseen in the VI class curriculum.
Sample variables: In this paper-experiment 12 variables were applied, 6 of which are morphological characteristics and 6 motor tests.

\section{Morhological Variables}

Body weight (BW), body height (BH), leg length (LL), arm length (AL), abdominal skinfold (AS), and biceps skinfolds (BS).

\section{Motor Test}

Standing Broad Jump (SBJ); Sit and reach (SR); Sit$\mathrm{Up}(\mathrm{SU}) ; 10 \times 5 \mathrm{~m}$ shtuttle test (10x5 shtuttle); Flexed arm hang test (FHT) and Plate Tapping (PT). Before carrying out this paper-experiment, the researchers involved in the project participated in the training to guarantee the standardization, validity and reliability of the measurements (Moreno et al., 2003). The tests were part of the EUROFIT test batteries, validated and standardized by the European Council.

\section{Statistical Analysis}

Statistical data were analyzed using the SPSS 21.0 version for Windows software, when statistical parameters were calculated by means of the statistical method: minimum value (Min), maximum value (Max), arithmetic mean (Mean), standard deviation (SD) and coefficient of variability $(\mathrm{KV} \%)$ as well as correlation between morphological characteristics and those motor tests that are treated by Pearson correlation.

\section{Results}

Based on the values presented in the table of basic parameters for morphological characteristics, the distribution of the results of these variables is partly heterogeneous. Testing in variables body height, leg lenght and arm lengthe are more homogeneous, this is proved by the standard deviation (SD) value as well as the coefficient of variability $(\mathrm{KV} \%)$ that is small compared to abdominal skinfold and biceps skinfols, which is normal to the density of the fatty tissue. Some variables abdominal skinfold and biceps skinfols a positive asymmetry is observed, while in other 
variables although the normal distribution of results is not verified, they do not have significant deviations from the normal distribution.

In Table 2 are presented the values of the basic static parameters of the motor tests, which do not differ much from the other authors' works parameters. The asymmetric distribution of results is more noticeable in the flexed arm hang, where a positive asymmetry has been shown, also in this test children are heterogeneous to other results with the variability coefficient $(\mathrm{KV} \%)$ of $74.44 \%$.

\section{Table 1}

Basic statistical parameters in the morphological space.

\begin{tabular}{lccccc}
\hline Variables & Min & Max & Mean & SD & KV\% \\
\hline BW & 27.70 & 46.20 & 35.70 & 4.88 & 13.66 \\
BH & 131.40 & 163.00 & 145.90 & 6.61 & 4.53 \\
LL & 71.10 & 93.70 & 82.80 & 5.87 & 7.08 \\
AL & 52.50 & 67.80 & 60.70 & 2.62 & 4.31 \\
AS & 3.00 & 14.00 & 4.94 & 2.78 & 56.27 \\
BS & 5.00 & 16.00 & 8.35 & 2.15 & 25.70 \\
\hline
\end{tabular}

BW: Body Weight; BH: Body Height; LL: Leg Length; AL: Arm Length; AS: Abdominal Skinfold; BS: Biceps Skinfols; Min: Minimum Value; Max: Maximum Value; SD: Standard Deviation; KV\%: Coefficient of Variability.

\section{Table 2}

Basic statistical parameters in the motor ability.

\begin{tabular}{|c|c|c|c|c|c|}
\hline Variables & Min & Max & Mean & SD & KV\% \\
\hline SBJ & 121.00 & 165.00 & 141.20 & 21.68 & 15.35 \\
\hline SR & 33.00 & 50.00 & 43.00 & 3.09 & 7.18 \\
\hline SU & 8.00 & 21.00 & 16.80 & 4.65 & 27.67 \\
\hline $10 \times 5$ shtuttle & 22.50 & 27.60 & 25.17 & 2.96 & 11.76 \\
\hline FHT & 0.00 & 27.00 & 9.00 & 6.70 & 74.44 \\
\hline PT & 10.00 & 14.10 & 11.90 & 0.66 & 5.54 \\
\hline
\end{tabular}

SBJ: Standing Broad Jump, SR: Sit and reach, SU: Sit-Up; FHT: Flexed arm hang test; PT: Plate Tapping; KV\%: Coefficient of Variability.

\section{Table 3}

Correlation between morphological characteristics and motor ability.

\begin{tabular}{lcccccc}
\hline Variables & BW & BH & LL & AL & AS & BS \\
\hline SBJ & 0.08 & 0.08 & -0.13 & 0.12 & -0.06 & -0.03 \\
SR & -0.09 & -0.06 & -0.08 & -0.08 & -0.19 & -0.22 \\
SU & 0.00 & 0.19 & 0.12 & 0.07 & -0.18 & $-0.53^{*}$ \\
10x5 shtuttle & -0.12 & -0.07 & -0.04 & -0.14 & -0.18 & -0.20 \\
FHT & -0.22 & -0.09 & -0.07 & -0.12 & $-0.29^{*}$ & $-0.49^{*}$ \\
PT & -0.03 & -0.09 & -0.04 & -0.07 & -0.07 & -0.11 \\
\hline
\end{tabular}

* Correlation is probability at level 0.05 
With the training of these two spaces expressed in the correlation analysis (Table 3 ) we notice that both spaces have low correlation values. Only three correlation values are significant at $0.05^{*}$, but these values have signs of negative values(-). Modarate negative corelations was shown biceps skinfols with motor tests, sit-ups with a coefficient of --.53*, while the other correlation is between biceps skinfols arm with flexed arm arm test with a coefficient of $-0.49 *$, while the last correlation in this case is between abdominal skinfols with flexed arm tone with a coefficient of -0.29 *. It is also characteristic that most of the correlation values have negative marks before the value. Those values give a true reflection of the low correlation ratios between morphological variables and motor ability.

This, however, enables us to conclude that the flexed arm test hangs for the age of the children of this paper-experiment, which measures their static force, is a difficult motor task to accomplish. As far as sit-up test results are concerned, up to a certain percentage of children are proboscis with a percentage of $27.67 \%$, as well as the distribution of results based on the frequency distribution indicate the appearance of a small positive asymmetry. Meanwhile, in other tests the distribution of results do not have significant deviations from normal distribution.

\section{Dicussion}

According to the review of results on morphological characteristics and motor ability we see that the presented results are a very important process in child development. Given the results of this paper-experiment we can present an estimate that females have good values of morphological characteristics and motor ability. Children in body mass variables from Macedonia have higher values of $5.1 \mathrm{~kg}$, while women from Albania have identical results, as well as Croatian women have a high value for $3.15 \mathrm{~kg}$ and $6.27 \mathrm{~kg}$ Italian ones (Pejčić et al., 2005; Todorovska et al., 2012; Jarani \& Qeleshi, 2013; Lovecichio et al., 2013). This shows that the children we have received for the paperexperiment have shown the same bodily mass with children from Albania, but the children from
Macedonia, Korca and Italy have shown lower values. When we compare the results and body height of children with our other measurements we see that children from Italy have shown 3.62 centimeters of higher value compared to our children, while children from Albania and Croatia have shown approximate values but by comparing with our children those from Albania have lower values for 1.9 centimeters, while those from Croatia with 1.26 centimeters, but children from Macedonia have shown high values compared to our children for 1.72 centimeters (Pejčić et al., 2005; Todorovska et al., 2012; Jarani et al., 2013; Lovecichio et al., 2013). Since the field of physical education is an important indicator in the growth and development of children, because these two characteristics are accompanied by many other factors that are not involved in this paperexperiment or are not intended to workexperiment. Since the field of physical education is an important indicator in the growth and development of children, because these two characteristics are associated with many other factors that are not involved or do not have the purpose of paper-experiment. Women in the biceps skinfols variable from Macedonia have higher values of 0.10 millimeters compared to the children we have received in the experiment (Todorovska et al., 2012). However, we will take for comparison with children from Prishtina we see that our children have shown higher values in body mass variables, body height, abdominal skinfold and bicpes skinfols while in the variables the length of the arm and the length of the leg have shown the lowest values of the children in our paperexperiment, as compared to the authors (Gjinolli \& Geci, 1998). The results of the motor ability are indicative of the explosive force of the lower extremities, the flexibility, the repetitive force, the static force and the movement frequency have reached a level of satisfactory development of these motor tests (Malacko, 2007; Ivković, 2008). If we take for comparison children from Prishtina we see that our children have lower values in these motor ability (Gjinolli, 1999). Between the motor test flamingo, volumes and the fat tissue in almost all age categories have negative correlation, while 
muscle mass, especially after the $9^{\text {th }}$ year is in positive correlation with the general balance. Voluminosity and fat tissue is negatively correlated with the test raising the trunk for 30 seconds. For both gender all anthropometric measures, except the muscle mass percentage have negative correlation with the test pull-ups endurance. For boys and girls in almost all categories, all anthropometric measures, even fat tissue have a positive correlation with the test palm dynamometry. For both gender in almost all age categories the voluminosity, which is more result of the fat tissue (passive mass) is negatively correlated with the coordination, agility and speed, while the muscle mass percentage is positively correlated (Kalac \& Gontarev, 2015). Therefore, such type tests should be considered in the system of various motor activities as well as systematic monitoring of the development of motor skills in women of this age group. Negative correlations existed between subcutaneous fat parameters with flexed arm hang test, as well as in some other tests had correlations, but was lower in subcutaneous fat settings (Monyeki et al., 2008). In one case it is also shown a statistically significant negative correlation is determined between subcutaneous fat through the use of motor ability, in particular flexed arm hang (Gontarev et al., 2014). The correlations presented by the foreign authors let us also understand the results we have presented in the experiment because negative correlations between subcutaneous fat parameters and motor ability have been reported. Taken from a perspective viewpoint and based on the very important information from this experiment we see that we have low correlation values between subcutaneous fat and motor ability, so in this experiment we have a diagnostic the initial state of these characteristics in children. Through this methodological approach to PE, it can be changed with the planning and organization of methodical organizational forms in lessons as real opportunities in schools where children attend the teaching process of $\mathrm{PE}$.

\section{Conclusions}

Based on this paper-experiment we can conclude that in general the goal was the correlation of the subcutaneous fat variables with the motor ability in females in which we will draw the general conclusion: Since the age of 11 is a new school age, then the realization of motor duties is relatively difficult task, which is conditioned by the development of bodily construct. Correlative correlations between morphological characteristics and motor ability are obtained real expected values but there is no strong correlation, respectively negative correlation between subcutaneous fat tissue variables with motor ability. Therefore, the results of this experiment will be in function of the practical value necessarily not only for the children of this age group but also beyond, it is also important that besides the variables of the subcutaneous fat and motor ones also be recognized other factors that have an impact great in transforcing children in general and physical education(PE) in particular.

\section{Acknowledgments}

The authors would like to thank every participant for his effort and time

\section{Conflict of Interest}

No external funding was received for this study.

\section{Funding}

The authors report no conflict of interest

\section{References}

Babin, J., Bavčević, T., \& Prskalo, I. (2010). Comparative analysis of the specially programmed kinesiological activity on motor area structural changes of male pupils aged 6 to 8. Odgojne Znanosti, 12(1), 79-96.

Badrić, M. (2011). Differences in motor abilities of male and female fifth and sixth grade pupils. Croatian Journal of Education, 13(2), 82-107.

Bavčević, T., Vlahović, L., \& Katić, R. (2008). Influence of specially programmed $\mathrm{PE}$ lessons on the structure of relation between morphological-motor area and 
basic kinesiological manifestations of 7-year-old pupils. Proceedings Book of the 5th International Scientific Conference on Kinesiology "Kinesiology research trends and applications, Zagreb: Faculty of Kinesiology, University of Zagreb, Croatia, 490-494.

Findak, V. (1997). Programiranje u tjelesnoj i zdravstvenoj kulturi. Zagreb: Školske novine.

Findak, V. (2003). Metodika tjelesne i zdravstvene kulture priručnik za nastavnike tjelesne i zdravstvene kulture. Zagreb: Školska knjiga.

Gjinolli, E. (1999). Hapësira motorike e nxënësve të moshës 11-12 vjeçare të Prishtinës. Acta Kinesiologica, 6(1), 22-27.

Gjinolli, E., \& Geci, B. (1998). Struktura morfologjike e nxënësve të Prishtinës të moshës 11-12 vjeçare. Acta Kinesiologica, (1), 5-15.

Gontarev, S., \& Ruzdija, K. (2014). The relationship between overweight, obesity and physical fitness among eleven and twelve-year-old Macedonian adolescents. Journal of Physical Education and Sport, 14(2), 178-185.

Ivković, I. (2008). The impact of morphological and motor dimensions on explosive strength of boys aged 11-12. Acta Kinesiologica, 2(1), 85-89.

Jarani, J., \& Qeleshi, A. (2013). The precalence of obesity in children and current level of physical activity in a city in transition. Journal of Physical Activity \& Sports, $1(1) ; 18-22$.

Kalac, R., \& Gontarev, S. (2015). Cross-correlation between the anthropometric mesasures and motor tests for students from 6 to 14 years. Research in Physical Education, Sport and Health, 4(2), 85-93.

Kryeziu, A., Abdullahimi, F., Rexhepi, J., Kica, K., Jashari, V., \& Hasani, H. (2014). Differences between children in some morphological indicators by physical educaiton's curriculm. Sport and Health, 1(2), 56-60.

Lovecichio, N., Merati, M., Guasti, M. Casolo F., \& Eid L. (2013). Cooper and shuttle run test in young students: results and correlations. Sport Science Review, 22(3-4), 217-228.

Madić, D., Popović, B., Pantović, M., Tumin, D., \& Cvetković, M. (2010). The impact of body composition on the performance of complex locomotive structures of girls 11-12 years of age. XLIX Kongres Antropološkog Društva Srbije sa Meñunarodnim Učešćem, Zbornik Sažetaka, Vrdnik, 110.

Madić, D., Popović, B., Tumin, D., Obradović, J., \& Radanović, D. (2011). The impact of motor abilities on the learning of gymnastics exercises of girls 11-12 years of age. In: M. Mikalački \& G. Bala (eds.), Proceedings Book: Exercise and quality of life (pp.323-328). Novi Sad: $\mathrm{U}$ of Novi Sad.

Malacko, J. (2007). Relations between variables of body volume and motor abilities with primary school girls. Acta Kinesiologica, 1(2), 76-80.

Mišigoj-Duraković, M. (2008). Kinantropologija-biološki aspekti tjelesnog vježbanja. Zagreb: Kineziološki fakultet Sveučilišta u Zagrebu.

Monyeki, K.D., Kemper, H.C.G., \& Makgae, P.J. (2008). Relationship between fat patterns, physical fitness and blood pressure of rural South African children: Ellisras Longitudinal Growth and Health Study. Journal of Human Hypertension, 22, 311-319.

Moreno, L.A., Joyanes, M., Mesana, M.İ., GonzalezGross, M., Gil, C.M., Sarria, A., Gutierrez, A., Garaulet, M., Perez Prieto, R., Bueno, M., \& Marcos, A. (2003). Harmonization of anthropometric measurements for a multicenter nutrition survey in Spanish adolescents. Nutrition, 19(6), 481-486.

Pejčić, A., \& Malacko, J. (2005). The ontogentic development of morphological characteristics and motor ability of body's and girls in early elementary school. Kinesiologia Slovenica, 11(2), 42-55.

Todorovska, L., Zivkovic, V., Nikolic, S., Pluncevic, J., Sivevska, E. Handziska, E., \& Karadjozova, I. (2012). Anthropometric characteristics of macedonian children at the age of 9-14 years. Research in Physical Education, Sport and Health, 1(1), 11-19.

Vlahović, L. (2012). Vrednovanje motoričkih znanja kod učenika petih razreda osnovne škole. Doctoral dissertation, Faculty of Kinesiology, University of Split, Croatia.

Vlahović, L. Babin, B., \& Babin J. (2016). Relationship between morphological characteristics and motor knowledge in eleven year-old female pupils. Croatian Journal of Education, 18(1), 137-156. 